Arab World English Journal (AWEJ) $2^{\text {nd }}$ Special Issue on Covid 19 Challenges January 2022 DOI: https://dx.doi.org/10.24093/awej/covid2.25

Pp. 377-392

\title{
Socrative as a Formative Assessment Tool in English for Specific Purposes Course
}

\author{
Maryna Kolisnyk \\ Department of English Language for Humanities \\ National Technical University of Ukraine "Igor Sikorsky Kyiv Polytechnic Institute \\ Kyiv, Ukraine \\ Correspondent Author: m.p.ruda@gmail.com \\ Yuliya Kornytska \\ Department of English Language for Humanities \\ National Technical University of Ukraine "Igor Sikorsky Kyiv Polytechnic Institute \\ Kyiv, Ukraine \\ Olga Ogurtsova \\ Department of English Language for Humanities \\ National Technical University of Ukraine "Igor Sikorsky Kyiv Polytechnic Institute \\ Kyiv, Ukraine \\ Olga Sokyrska \\ Department of Technical English №2 \\ National Technical University of Ukraine "Igor Sikorsky Kyiv Polytechnic Institute, \\ Kyiv, Ukraine
}

Received:11/30/2021

Accepted: $1 / 7 / 2022$

Published: $1 / 24 / 2022$

\begin{abstract}
Many factors influence the development of the educational system, and today it is a global COVID-19 pandemic. Stakeholders in the educational process need to adjust to a new distant reality without compromising the quality. The formative assessment proved to be a suitable approach to overcome existing challenges, and one of the most popular tools to facilitate it is Socrative. The study aims to 1) investigate student attitudes and the correlation between academic achievements in ESP and majors and 2) present our experience in utilizing Socrative for formative assessment in a distant mode in the settings of the National Technical University of Ukraine "Igor Sikorsky Kyiv Polytechnic Institute." To achieve the goals of our study, we have developed and validated a questionnaire, collected quantitative data, analyzed and interpreted the qualitative data; the study sample included 137 students. The obtained results have shown the general positive student attitude towards the usage of Socrative within the course of ESP due to its efficacy, personalization, and responsiveness. The results can be a perspective for further investigation despite some limitations.
\end{abstract}

Keywords: distant learning, English for specific purposes, formative assessment, internet service, Socrative, student attitude, Ukraine context

Cite as: Kolisnyk, M., Kornytska, Y., Ogurtsova, O., \& Sokyrska, O. (2022). Socrative as a Formative Assessment Tool in English for Specific Purposes Course Arab World English Journal (AWEJ) $2^{\text {nd }}$ Special Issue on Covid 19 Challenges (2)377-392. DOI: https://dx.doi.org/10.24093/awej/covid2.25 
Arab World English Journal (AWEJ) 2nd Special Issue on Covid 19 Challenges January 2022

\section{Introduction}

The constant change of society requires educational professionals to adopt the methodology they use to teach ESP, improve their skills, whether they are classic rhetoric or modern information technologies, and make their classes interactive, motivating, and effective.

The potential of digital resources, while integrated into the educational process, allows practitioners to solve effectively many didactical tasks - this potential raises the level of content visualization, enhances the intensity and information density of the educational process. It ensures a higher level of engagement in course activities which is especially relevant while working with passive students.

Digital tools activate thinking processes, develop the skills of autonomous work with materials, shape computer literacy and digital awareness; they provide instant and efficient feedback and implement individualized and differential approaches to education. The capacity of information technologies within the ESP course plays an essential role in its formation and becomes an indispensable element of qualitative teaching.

More than a year ago, a global society faced a new challenge: a pandemic of COVID-19 caused by the SARS-Cov-2 virus, better known as simply coronavirus.

Educational facilities worldwide had to switch gears and introduce the distance mode to follow the World Health Organization recommendations (WHO, 2020) of physical distancing to prevent the spread of the disease - hence - technology not only facilitates our routine and provides entertainment but also gives us the possibility to work and study remotely.

Digital tools, in the current demanding circumstances, support the regular flow of the training activities in the distant mode but also upgrade the process as such - digital devices, application programs, web-based services allow to create an interactive learning environment even distantly. The prior tendency for digitalization of the educational process has helped the transition from auditoriums into telecommunication systems and streams, YouTube channels.

Formative assessment, nevertheless, stayed one of the crucial aspects in the teaching and learning process that still prioritized traditional question-answer sessions or paper-based tests. The long-standing practice to assess only the final results should entail the assessment of the gains and acquired modalities of actions en route for strengthening the training process.

At the same time, the practitioners experience a lack of techniques and effective methods for incremented meta-subject results assessment. In this process, it is crucial to alter the procedure. The procedure should be as clear and transparent as personally meaningful for students. These aspects incite the interest in formative assessment and, as a result, bring it to the fore.

Currently, researchers outline four main goals of formative assessment:

1. The most considered objective is to provide feedback on student performance (McLaughlin \& Yan, 2017; Hira et al., 2020).

2. Improving student understanding of the subject matter is equally sufficient (Ismail et al., 2019). 
3. Furthermore, educators and learners accentuate the perspective to enhance and accelerate learning (Prashanti \& Ramnarayan, 2019).

4. Researchers emphasize the potential to encourage students to study, acquaint them with their progress and gaps to fill (Weurlander et al., 2012; Hill, Wong \& Thal, 2019; Koyantayeva, 2019).

To meet all of the above aims within the distance mode of the educational process, lecturers started to use web-based, online alternatives. This research focuses, specifically, on Socrative as one of the most popular digital instruments for implementing formative assessment (Royer, 2016; Pryke, 2020).

Socrative is a web service. The service is freemium (with a paid option for added features) and offers a set of tools for formative assessment activities. This web-based service is a universal cross-platform application available for different devices from smartphones, tablets to desktop computers.

This service allows creating new polls, tests, or quizzes right during the joint session of teachers and students working with the platform - it is as if working in a virtual room where a teacher is a manager authorized to start surveys, create new ones, set the pace and mode of the process, et cetera.

Students, through their mobile devices or computers, join the activities. They can answer the questions under their names or anonymously, depending on the mode of use provided by a teacher.

A teacher registers to access a personal page with a unique room code necessary for students to access the tests.

With Socrative, offering multiple-choice and open-ended questions, a teacher needs to go to the Quizzes tab to create a test; to go to the Launch tab and click on the quiz button to start. The next step is to decide on a test method; the platform offers three options to choose from Instant Feedback, Open Navigation, and Teacher Paced:

1. Working in the Instant Feedback mode, students get feedback after each response.

2. The Open Navigation mode enables students to answer questions in any order and change answers before completing the test.

3. And, the Teacher-Paced mode permits monitoring the flow of questions and tracking the responses as they arise- a teacher can skip and come back to the questions if necessary.

After choosing the test mode method, the final step is to start the test using the start button. The completed test gives an instant opportunity to check student progress remotely. One of the unique features a teacher can benefit from is the time-controlling function allocated for the stages of the activity. At the teacher's choice, the students can perform the test at their own pace or in the strict time mode controlled by the teacher. The system also allows tracking in real-time how many students have completed the test and how many correct answers they have given. The platform interface is intuitive and user-friendly, so there are no special requirements for 
computer literacy and information technology background. There are three main plans of Socrative: No fee, Socrative PRO for school teachers, Socrative PRO for higher educators and professionals. Figure 1 represents the features of the plans mentioned above.

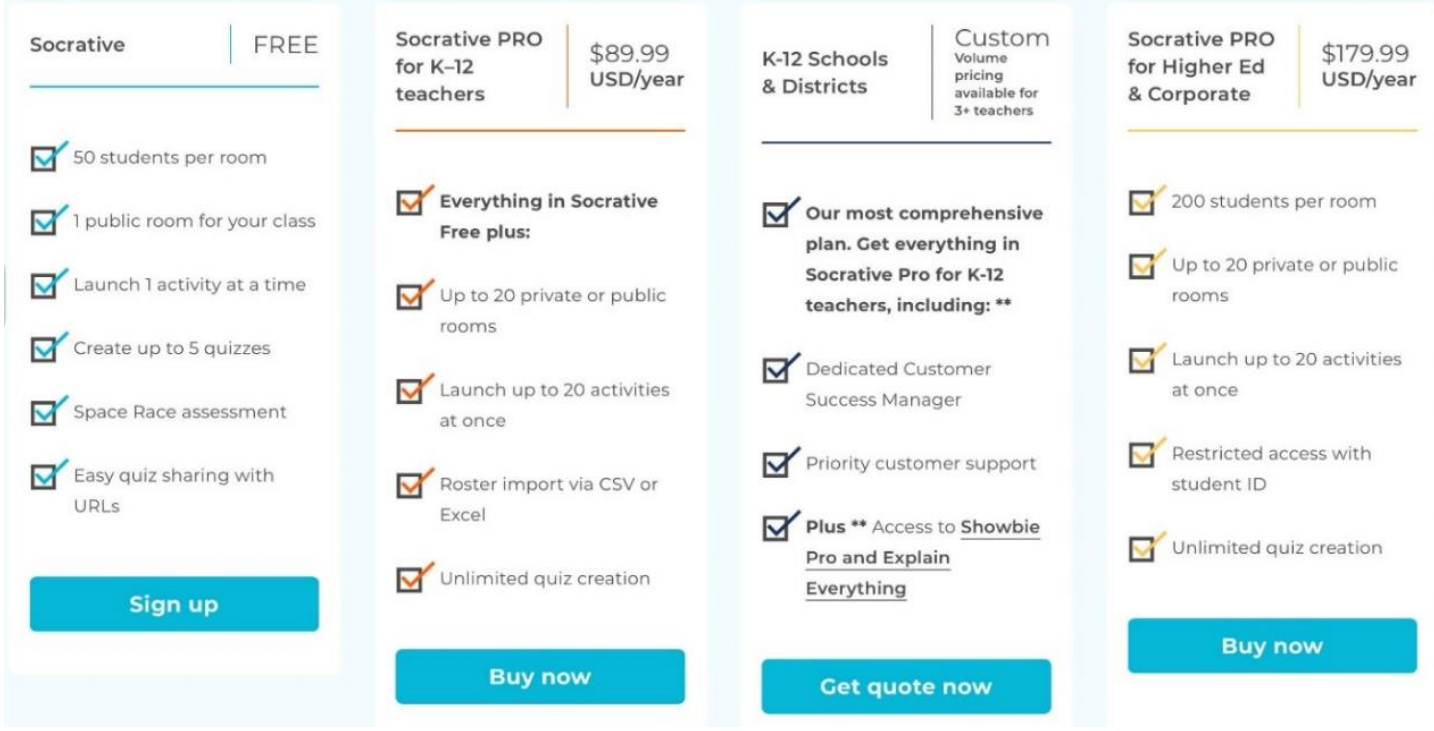

Figure 1. Socrative Feature Comparison and Plans (Socrative, 2021)

Figure 1. shows that all the main features for the successful formative assessment are available equally through all plans, thus enabling any lecturer to introduce the service into their curriculum without extra expenditure. If premium features are essential for the educational process, the teacher or the institution buys the corresponding packet. Students get free access to all the Socrative services for them no matter what plan to use. Therefore, implementing this webbased service makes it student-friendly and effective for the learning and assessment processes.

\section{Literature review}

According to an official site Socrative currently has nearly three million users worldwide and is available in 14 languages (Socrative, 2021). This application brings fun, effective engagement and on-the-fly assessments into the educational process; it has a user-friendly, uncluttered, relatively intuitive interface that allows students and lecturers with different information technology backgrounds and expertise to comprehend and utilize the service during their lessons. Furthermore, the variety of features available to each user despite the plan grants the popularity of Socrative.

- The application provides instant feedback that enables teachers to assess student understanding on the fly and adjust their materials and teaching techniques (Batool, Mumtaz, Ali \& Chughtai, 2018).

- The range of personalized activities can satisfy the demands of specialists in different spheres. One can create quizzes, polls, ticket-to-leave activities, multiple or binary choice tests, short open questions. Moreover, lecturers can prepare the 
assignments beforehand, save them as templates, and reuse them with different groups.

- Socrative allows users to visualize either group or individual progress clearly;

- It enables lecturers to indicate complexities on the go and provide students with instant feedback. This feature can be beneficial for managing the learning process in groups where active involvement in the lesson progress may otherwise be insufficient (Cerqueiro \&Harrison, 2019).

- This online platform permits the lecturer to involve the usage of smartphones (which usually distract students from lectures) in the educational process, thus following the proverbial "If you cannot beat them, join them" (Pryke, 2020, p.70).

- Students may appreciate the opportunity to get individual or group tasks, submit anonymous answers, or even participate in a friendly competition.

Regarding the positive aspects of Socrative listed above, it seems logical that teachers and lecturers worldwide study it and try to introduce this application program into their curriculum. The geography of the study includes participants from different regions: Spain (Badia et al., 2016), Croatia (Tretinjak et al., 2015), Turkey, Pakistan (Batool, Mumtaz, Ali \& Chughtai, 2018; Moin et al., 2020), Malaysia (Lim, 2017), the UK (Pryke, 2020), Ireland (Rae and O'Malley, 2017), the USA (Guarascio et al., 2017) and others. In Ukraine, the studies of Socrative include field research among medical students (Khaskhachykh, 2018; Potapov et al., 2017) or, as one of the components of adaptive technologies, personal response systems (Zavizion, 2020; Marienko et al., 2020).

At the same time, the publications on Socrative show a variety of approaches to studying this online assessment system: most studies show the student attitude to the Socrative as a clicker device (Rae and O'Malley, 2017; Lim, 2017; Batool, Mumtaz, Ali \& Chughtai, 2018; Cerqueiro \&Harrison, 2019; Pryke, 2020); others regard Socrative as an assessment tool that benefits students and lecturers (Socrative Student and Socrative Teacher modules) who are inseparable parts of the education process, yet considered as partly different (Nawalaniec, 2015; Moin et al., 2020).

The studies we surveyed within the scope of this research show a positive attitude towards Socrative and the high efficiency of its implementation. Pryke mentioned the only deviation from this tendency (2020) when surveyed students majoring in physics. The obtained results indicated that the approval of Socrative is adequate to the level of subject complexity - the more complicated the topic is, the lower is enthusiasm to use the online response system.

These studies, being taken together, support the notion that, overall, the Socrative is an efficient online tool for the progress evaluation of students. At the same time, all of the studies above took place during the pre-pandemic period, thus regarding Socrative as an additional alternative alongside the traditional in-class, off-line formative assessment methods. While the current context has fostered the shift of forms, making this alternative into principal to boost and facilitate online class or maintain physical distance in a classroom. Moreover, the courses under study were of a specialty nature, and students who participated in the researches were from one specific department. Thus researchers were not considering the possible differences in attitudes towards one subject of representatives with different majors.

Assuming the absence of research in Ukraine, the current study aims to: 
1) share a piece of our practical experience; 2) present a clear vision of student view to Socrative, and 3) analyze the correlation between academic achievements in ESP and majors in the settings of the National Technical University of Ukraine "Igor Sikorsky Kyiv Polytechnic Institute."

This study targeted the following research trajectories:

1. Student attitudes and perceptions of Socrative as a formative assessment tool.

2. Correlation between student attitudes to Socrative and their academic achievements and majors.

\section{Method}

A field test aimed to study the targeted research trajectories that followed a three-phase methodology to collect and interpret the data. The first phase aimed to develop and validate the questionnaire. In the second phase, the quantitative data was collected and analyzed. The focus of the third stage was the interpretation of the obtained results through the qualitative data.

\section{Participants and procedure}

The study sample comprised 137 students: 67 students majoring in Economics and 70 students majoring in Computer Sciences taking the ESP course- out of the selection of 137 students, 124 students completed and submitted the questionnaire- this translates to a sufficient (for our study) response rate of $90.5 \%$.

Students' final semester ESP grade out of 50 was 32.1 with a standard deviation of 9.5. The minimum approval grade was 25 out of 50. In addition, ESP grade and standard deviation were as follow: FMM=32.5 (9.3) and FICT =31.6 (9.7). The standard deviation was rather high since underachievers affected the general average score.

The questionnaire was administered to the students at the end of the experiment and took approximately 15 minutes to complete.

\section{Instrument}

To collect information on the attitudes regarding Socrative in their ESP course, we developed and administered a questionnaire. The research employed quantitative and qualitative as complementary methods since the devised questionnaire included both types of questions, open-ended and close-ended. It required twenty-eight days to design the instrument. Having analyzed the existing experience and surveys, the authors decided on four-dimensional blocks appropriate for the study. The survey instrument consists of 18 items on a five-point Likert scale (from Strongly Disagree=1 to Strongly Agree=5) and has four-dimensional Blocks: Advantages, Usability, Engagement and Motivation, Attitude (Table 1).

Table 1. The questionnaire statements

\begin{tabular}{|c|c|c|c|}
\hline Block 1 & Block 2 & Block 3 & Block 4 \\
& & & \\
Advantages & Usability & Engagement & Attitude \\
\hline
\end{tabular}


Arab World English Journal (AWEJ) 2nd Special Issue on Covid 19 Challenges January 2022

\begin{tabular}{|c|c|c|c|}
\hline & & $\begin{array}{c}\text { and } \\
\text { Motivation }\end{array}$ & \\
\hline $\begin{array}{l}\text { Answering questions with } \\
\text { Socrative is more } \\
\text { comfortable than in other } \\
\text { modes. }\end{array}$ & $\begin{array}{l}\text { It is easy to understand } \\
\text { how does Socrative works. }\end{array}$ & $\begin{array}{l}\text { I study harder to succeed } \\
\text { in individual activities } \\
\text { with Socrative. }\end{array}$ & $\begin{array}{l}\text { My experience with } \\
\text { Socrative is positive. }\end{array}$ \\
\hline $\begin{array}{l}\text { Socrative enables me to } \\
\text { see my progress, } \\
\text { achievements, and gaps by } \\
\text { providing summarized } \\
\text { feedback. }\end{array}$ & $\begin{array}{l}\text { I find Socrative easy to } \\
\text { use. }\end{array}$ & $\begin{array}{l}\text { I feel responsible for team } \\
\text { achievement in group } \\
\text { activities and force myself } \\
\text { to study more. }\end{array}$ & $\begin{array}{l}\text { I would use Socrative } \\
\text { permanently. }\end{array}$ \\
\hline $\begin{array}{l}\text { I receive feedback from } \\
\text { my teacher with no delays. }\end{array}$ & $\begin{array}{l}\text { The interface is user- } \\
\text { friendly. }\end{array}$ & $\begin{array}{l}\text { I am more attentive in } \\
\text { classes with Socrative than } \\
\text { without it. } \\
\text { I am more engaged in } \\
\text { classes with Socrative. }\end{array}$ & $\begin{array}{l}\text { Classes with Socrative are } \\
\text { more enjoyable than } \\
\text { without it. }\end{array}$ \\
\hline $\begin{array}{l}\text { I receive immediate } \\
\text { feedback on my } \\
\text { understanding of the } \\
\text { material. }\end{array}$ & $\begin{array}{l}\text { I can run it on my } \\
\text { computer or mobile } \\
\text { device. }\end{array}$ & $\begin{array}{l}\text { I am more involved in } \\
\text { learning during classes } \\
\text { with Socrative. }\end{array}$ & $\begin{array}{l}\text { Testing with Socrative is } \\
\text { less stressful for me. }\end{array}$ \\
\hline $\begin{array}{l}\text { I can assess my } \\
\text { understanding by } \\
\text { comparing my results with } \\
\text { the other students' results } \\
\text { during the class. }\end{array}$ & & & \\
\hline
\end{tabular}

We piloted the questionnaire with 35 volunteer students experienced in using Socrative but not participating in the experiment to assess its validity.

We checked the reliability of the questionnaire through the Cronbach alpha test with SPSS. The final version was highly reliable $(\alpha=.97)$. The correlation coefficients $(r)$, analyzed with the Pearson correlation coefficient, were high/positive.

For the processing of the numerical data, we employed statistical analysis software. The processing of the extended responses collected from the open-ended questions involved Nvivo. In this way, we ensured robust and accurate data analysis.

\section{Implementation}

"The current shift in education paradigm tasks teachers to refocus their teaching strategies and adopt new approaches to meet new challenges, incorporate facilitative technologies, and provide models and opportunities for effective and ample practice. In this context, online Student Response Systems are getting more and more attention from practitioners and researchers" (Kornytska, 2020). 
The didactic and methodological potential of web-based response systems also turned our attention. We aimed to facilitate the distant mode learning process and make it more effective and engaging.

In this study, the authors used the Socrative Student Response System. We utilized the system for 16 weeks in the first (autumn) semester of the 2020-21 academic year. The weekly ESP class lasted 90 minutes. The authors used Socrative for approximately 25 minutes for each class session: the students were given 5-minutes session at the beginning of every lesson to revise and recall the material, a 10-minutes session to complete one of the in-class tasks, and 10 minutes to sum up the session. Other in-class activities we conducted were unrelated to Socrative. We used Socrative only for formative feedback: students worked individually or in small teams answering the questions demonstrated by the teachers; the progress, the rate of correct answers, and succeeding participants were on the screen. As a second step, we analyzed the correct responses rate for each question, then we discussed and explained the questions with a low rate of correct answers in groups. A sample screenshot demonstrating an example of a question posed to students (student view) is in Figure 2. The samples of screenshots that show progress in a team activity and the rate of correct answers in an individual task are in Figures 3 , 4 , and 5.

\section{3 of 8}

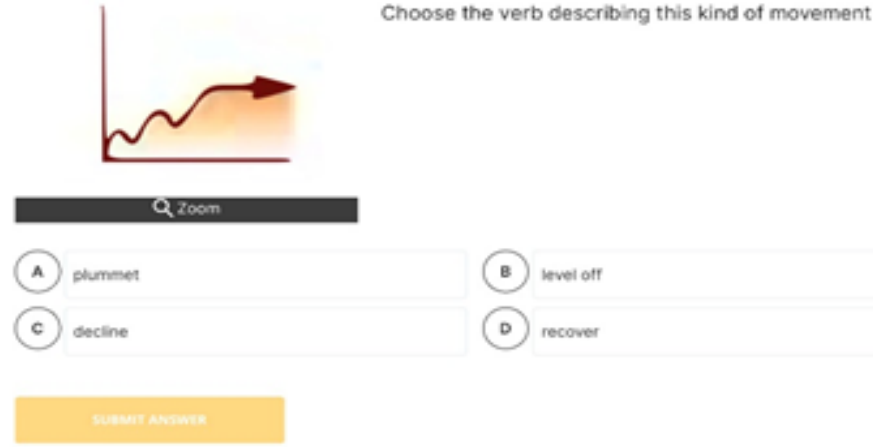

Figure 2. A screenshot demonstrating an example of a question shown on student screens

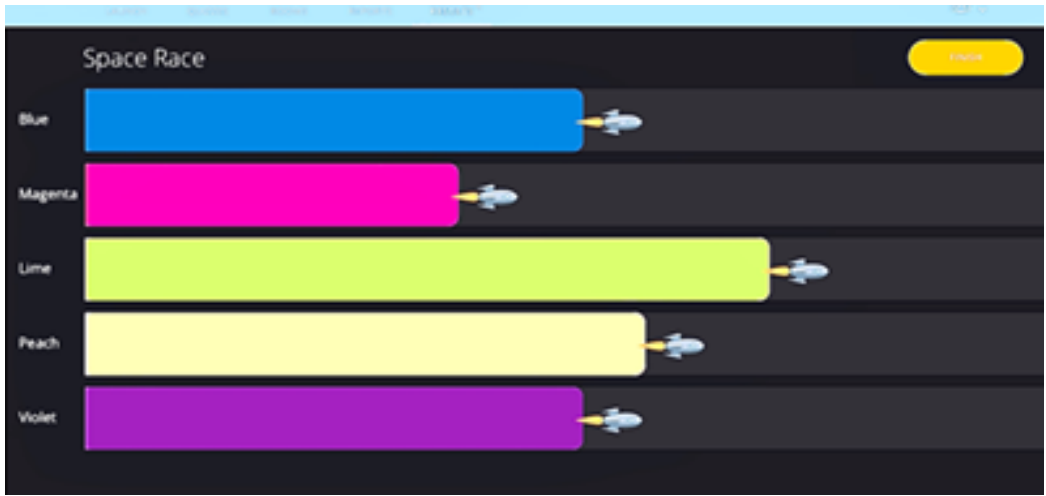

Figure 3. A screenshot demonstrating progress in a team activity 


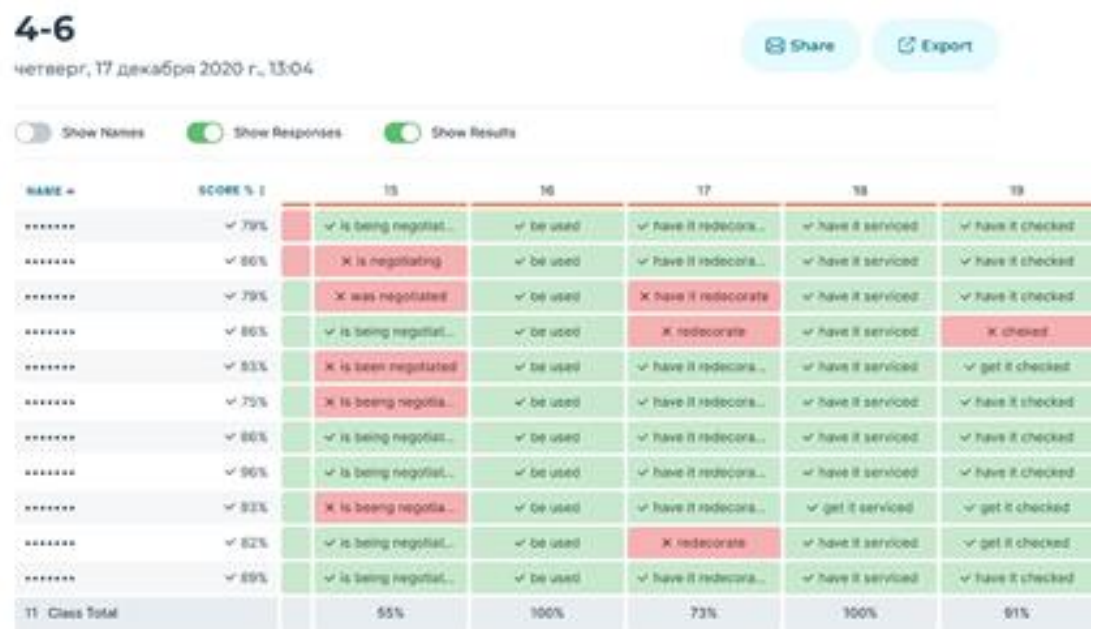

Figure 4. A screenshot demonstrating the rate of correct answers in an individual activity with multiple-choice questions

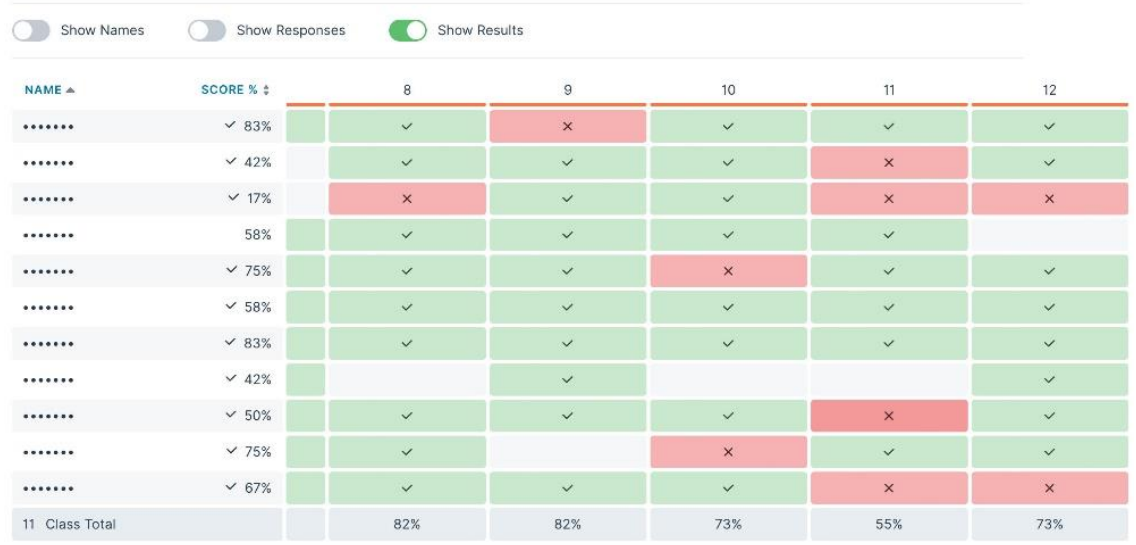

Figure 5. A screenshot demonstrating the rate of correct answers in an individual activity with open-ended questions

\section{Results}

\section{Student attitude and experience}

The first research question delved into student attitudes towards utilizing Socrative as an in-class formative assessment tool for 16 weeks and their experience.

Student attitude was analyzed in four dimensions: advantages, usability, engagement and motivation, experience. The responses were, in general, predominantly affirmative; the average score on the questionnaire was 4.03 , demonstrating a highly positive attitude and expertise. The relative frequencies of reactions (as a percentage for the comparison easiness) are in Table 2.

Table 2. Frequency of responses for dimensional blocks

\begin{tabular}{|c|c|c|c|c|c|}
\hline Block & $\begin{array}{c}\text { Strongly } \\
\text { disagree }\end{array}$ & Disagree & Neutral & Agree & Strongly agree \\
\hline Advantages & 0 & 0 & 0 & 31.45 & 68.55 \\
\hline
\end{tabular}


Arab World English Journal (AWEJ) 2nd Special Issue on Covid 19 Challenges January 2022

\begin{tabular}{|c|c|c|c|c|c|}
\hline Usability & 0 & 8.87 & 12.1 & 25.81 & 53.23 \\
\hline $\begin{array}{c}\text { Engagement } \\
\text { and Motivation }\end{array}$ & 0 & 4.03 & 9.68 & 29.03 & 57.26 \\
\hline Attitude & 0 & 1.61 & 15.32 & 39.52 & 43.55 \\
\hline
\end{tabular}

As can be seen, the percentage for Strongly Agree and Agree is the most for all the blocks, and it was an early positive indicator - students mostly favored Socrative, and the results made it clear.

Block 1 (Advantages) had very one-sided results: $31.45 \%$ and $68.55 \%$ chose to agree and strongly agree; in the extended responses section, students pointed out that they were less likely to receive instant feedback from teachers as often as they would prefer and appreciated this Socrative feature very much (in $70,16 \%$ ).

The respondents considered Socrative an effective tool to receive feedback and reflect on their performance. The participants also mentioned: time-saving (appeared in 42,6\%); better focus (appeared in 22,8 \%), and no distractors (appeared in 26,4 \%) since we demonstrated only one question on a screen at a time - a clear picture of the progress that facilitated the improvement of a learning curve is the mutual idea expressed in various but close in meaning forms (appeared in $54.84 \%$ ).

Block 2 (Usability) received mixed results from respondents - while no one strongly disagreed, and only 8,87\% disagreed, there were $12.1 \%$ of students who stayed neutral. The median and mode central tendencies indicated that participants evaluated the usability positively, although there was a dispersal of responses. In their extended responses, the students noted that $i t$ took time and effort to understand the features (appeared in $4.03 \%$ ), mentioned problems with battery life (1.61\%), and with Internet connection $(17.74 \%)$. The vast majority used smooth, easy, user-friendly, and intuitive in various but close-in-meaning words.

Block 3 (Engagement and motivation). The results demonstrate that the grand mean of the responses indicates a positive tendency. The students felt they performed more actively in and for the ESP classes. A high level of self-reported engagement and motivation mediated employing Socrative reported $87 \%$ of participants who strongly agreed and agreed $(29.03 \%$ and $57.26 \%$ respectively) with the statements presented in the block.

While 86, $29 \%$ agreed or strongly agreed that they studied more intensively and paid more attention to the course content to succeed in Socrative activities, $9.68 \%$ stayed neutral, and 4.03 indicated the demonstrated negative perceptions. The extended responses section comprised the positive aspect of enhanced engagement (appeared in 6,2\%), competing and winning (appeared in 18.4\%), responsibility, and reputation (32,8\%). As for neutral and negative responses, my motivation had been high enough and was not affected by the tool appeared in 5, 
Arab World English Journal (AWEJ) 2nd Special Issue on Covid 19 Challenges January 2022

9\%, had other priorities (in $1.61 \%$ ), need more time to understand and analyze the effect (in $1.61 \%)$.

Block 4 (Attitude). Approximately $83 \%$ of the recipients perceived Socrative as an effective tool that provided new, positive, and beneficial in-class experiences. The respondents used the words enjoyed, fun, motivational, stimulating to describe their attitudes and experiences. However, there were 15,32 \% of students who stayed neutral. They provided extended responses clarifying that they were satisfied with traditional in-class workflow but appreciated the diversity. The other remarks regarding attitudes and experience were - wish to try something else to compare (12.9\%), would prefer to try more game-based platforms (6.45\%), experienced even more stress while being tested (1.61\%).

Participant perceptions of the study dimensions are generalized, compared, and depicted in Table 3. As seen from Table 3, the means of advantages and engagement blocks stand higher in the ranking than usability and attitude.

Table 3. Participant perceptions of the study dimensions

\begin{tabular}{|c|c|c|c|}
\hline Dimensional block & $\sum \mathbf{x}$ & Mean & Rank \\
\hline Advantages & 581 & 4.6 & High \\
\hline Usability & 525 & 4.2 & Medium \\
\hline $\begin{array}{c}\text { Engagement and } \\
\text { Motivation }\end{array}$ & 545 & 4.4 & High \\
\hline Attitude & 527 & 4.3 & Medium \\
\hline
\end{tabular}

\section{Correlation between attitudes to Socrative, academic achievements, and majors}

The second research question addressed the correlation between student attitudes to Socrative and their academic achievements and majors. T-test aimed to detect variations in the attitudes of students majoring in Economics and students majoring in Computer Sciences. Correlation analysis aimed to identify a linkage between term final grades and student attitudes towards Socrative. There was no substantial discrepancy $(\mathrm{p}=.091)$ between the FMM and FICT student attitudes. The correlation analysis revealed an insignificant $(\mathrm{p}=.278)$ correlation of -.156 between the participant attitudes and first-semester final grades. The correlation between attitudes and the first-semester final results was also the object of examination regarding the participants majoring. A significant correlation was evident neither between FMM student grades and attitudes nor between FICT students. Consequently, we can conclude that Socrative is a generic instrument for implementing formative assessment. 
Arab World English Journal (AWEJ) 2nd Special Issue on Covid 19 Challenges January 2022

Socrative as a Formative Assessment Tool in English

Kolisnyk, Kornytska, Ogurtsova \& Sokyrska

\section{Discussion}

The obtained results affirm the positive attitude towards using Socrative as an in-class formative assessment tool in the settings of the Ukrainian university and come in correspondence with the reported positive results from Japan (Ohashi, 2015), Ireland (Rae \& O'Malley 2017), the United States (Guarascio et al. 2017), Chile (Gómez-Espina et al. 2019).

The positive experience and attitudes we obtained upon sixteen weeks of utilizing Socrative in class The analyses of the results from Block 1 (Advantages) demonstrate that the system was accepted positively because of its advantages compared to traditional formative assessment practices. And these findings match those made by Cerqueriro and Harrison (2019), and, in all cases, the comparisons were favorable. The participants appreciated time-saving, immediate feedback, and summarized feedback, also mentioned by other researchers (Rae \& O'Malley, 2017). The positive effect on the learning curve and more focused environment reported by the participants in this study were also present in studies by Vettori et al. (2020), Wood (2020), Ziemann, and McKenzi (2020).

The results from Block 2 (Usability) are mainly in line with the several findings presented overwhelmingly positive student feedback regarding the Socrative usability - the vast majority of the participants describe the utilization of Socrative with smooth, easy, user-friendly, intuitive, and other various but close-in-meaning words.

However, some authors mention technical issues as a vital prerequisite for Socrative utilization id est owning portable equipment and permanent Internet access. We also obtained responses that highlighted not solely positive experiences related to technical issues.

As for owning a mobile device, we can consider this issue as non-existing in the context of Ukrainian university, but Internet and Wi-Fi connection problems remain vestigially unsolved. The respondents in their responses related the usability of Socrative closely to the technicalities such as availability, speed, stability, and quality of the Internet connection. There are also some references to the problem in a range of studies. In some cases, the technicalities were attributed as one of the most critical dimensions, while others reported the issue as negligible (Guarascio et al., 2017). The participants in our study reported Internet connection-related problems in $17.74 \%$ since they learned in a distant mode from different parts of Ukraine (due to the COVID-19, the autumn semester was a distant-mode one). In the Campus settings, with permanent Internet access, these obstacles would not be relevant.

The findings from Block 4 (Engagement) and motivation support the conclusions of Rofiah and Waluyo (2020), Ziemann and McKenzi (2020), and many others. The feedback from the respondents evidenced the overall positive trajectory. The participants reported a higher level of engagement, interest, involvement, and motivation. Therefore, we can deduce that utilizing Socrative fosters and enhances student learning that is significantly valued while working with crowded groups, low-achievers, and students who are reluctant to answer.

While utilizing SRS systems for formative assessment is becoming more and more popular, there is still a lack of studies related to the issues of academic integrity and cheating. Due to the availability of applications and online services, the opportunities to cheat while being 
tested via online SRS are significant, and related cases are challenging to detect. The results obtained in this study revealed that the possibilities for cheating are closely associated with the testing strategy. We shaped the system to eliminate the possibility of cheating in a distant mode of learning. Teachers demonstrated test questions via a step-by-step manner, presenting one question at a time. It helped to prevent a copy-paste approach. In addition, we set a time limit for answering. Students with a fluent understanding of the material can usually meet time. Students with limited or no knowledge need extra time to search for the information to answer the question.

In our practice, we offered students various types of questions- not only multiple-choice questions but also questions requiring short or extended answers, making their responses as individual as possible. This strategy proved to be effective - since, for instance, while being tested in a teacher-paced mode, only $4.84 \%$ of the recipients reported attempts to cheat. It slightly contradicts the results presented by Rofiah and Waluyo (2020). "Thai EFL learners confirmed the ease of cheating when having online tests using Socrative" (Rofiah \&Waluyo, 2020). Our approach and results align with the findings of Costely, who addressed cheatingrelated issues and concluded that teachers could influence the situation (2017).

Moreover, we agree with Kocdar et al. (2018) that we should not blame students for the low trust and cheating in online formative tests. The process of developing awareness that academic integrity breaching and cheating compromise their results and achievements should be an integral part of a teaching process.

We focused attention on the academic integrity basics and code in our practice. Within the first step, we presented students with a poster with rules explaining the basics of academic integrity. Next, we discussed the problems and negative influences related to cheating. Finally, we demonstrated the banner with the basic rules and reminders before each testing session. These measures served as additional control elements and invisible pressure to ensure academic integrity.

\section{Limitations}

The study has some limitations related to the Block 5 Academic integrity because it rests on self-reporting. Therefore, there is a possibility that respondents did not reveal a genuine attitude since academic integrity and cheating are sensitive issues. The findings of this study should be treated only contextually. Further research is recommended to explore the issue.

\section{Conclusion}

The results of the current study have proven that using Socrative as an in-class formative assessment tool in the settings of the Ukrainian university was a positive experience. Students have highly appreciated its time-saving and feedback features. Moreover, the high involvement and efficiency gains in the student educational process granted the general positive attitude. At the same time, no significant correlation was found between FMM student grades and attitudes and between FICT students. The overall results prove the versatility of the online service under study. 
Arab World English Journal (AWEJ) 2nd Special Issue on Covid 19 Challenges January 2022

\section{About the authors:}

Maryna Kolisnyk is a Ph.D. Associate Professor of the Department of English Language for Humanities, National Technical University of Ukraine "Igor Sikorsky Kyiv Polytechnic Institute". Her research interests lie in the area of dialectology, English language variants, online services for English for Specific Purposes. ORCID: https://orcid.org/0000-0002-6697-5850

Yuliya Kornytska is a Ph.D. Associate Professor of the Department of English Language for Humanities, National Technical University of Ukraine "Igor Sikorsky Kyiv Polytechnic Institute". Her research interests lie in the area of English for Specific Purposes with a particular focus on technology-based teaching. ORCID: https://orcid.org/0000-0002-4781-0807

Olga Ogurtsova is a Ph.D. Associate Professor of the Department of English Language for Humanities, National Technical University of Ukraine "Igor Sikorsky Kyiv Polytechnic Institute". Her research interests are in teaching business English in digital age. ORCID: https://orcid.org/0000-0002-0828-3303

Olga Sokyrska is a Ph.D. Senior Teacher of the Department of Technical English №2, National Technical University of Ukraine "Igor Sikorsky Kyiv Polytechnic Institute". Her research interests include the linguistics, experimental phonetics, prosodic organisation of speech and teaching phonetics to ESL students. ORCID: https://orcid.org/0000-0001-8100-9709

\section{References}

Batool, H., Mumtaz, A., Ali, S., \& Chughtai, A. S. (2018). Positive trend shifting to online assessments: A review of using Socrative in medical college, its advantages and challenges faced. Journal of Medical Education, 17(3), 160-167. DOI: 10.22037/jme.v17i3.21694.

Cerqueiro, F., \& Harrison, A. (2019). Socrative in higher education: game vs. other uses. Multimodal Technologies and Interaction, 3, 49, doi: 10.3390/mti3030049

Costley, J. (2017). The instructional factors that lead to cheating in a Korean cyber university context. Interactive Technology and Smart Education, 14(4), 313-328.

Gómez-Espina, R., Rodríguez-Oroz, D., Chávez, M., Saavedra, C., \& Bravo, M. (2019). Assessment of the Socrative platform as an interactive and didactic tool in the performance improvement of STEM university students. Higher Learning Research Communications, 9 (2). DOI: 10.18870/hlrc.v9i2.452.

Guarascio, A. J., Nemecek, B. D. \& Zimmerman, D. E. (2017). Evaluation of students' perceptions of the Socrative application versus a traditional student response system and its impact on classroom engagement. Currents in Pharmacy Teaching and Learning, 5, 808-812. DOI: 10.1016/j.cptl.2017.05.011.

Hill, R., Wong, J., \& Thal, R. (2019). Formative assessment and its impact on student success, Nurse Educator, 44 (4). DOI: 10.1097/NNE.0000000000000530

Ismail, M., Ahmad, A., Mohammad, J. et al. (2019). Using Kahoot! as a formative assessment tool in medical education: a phenomenological study. BMC Med Educ 9, 230. DOI: $10.1186 / \mathrm{s} 12909-019-1658-\mathrm{z}$ 
Arab World English Journal (AWEJ) 2nd Special Issue on Covid 19 Challenges January 2022

Khaskhachykh, D. A. (2018). Vykorystannia internet-servisu Socrative dlia dystantsiinoho navchannia studentiv. (Internet service Socrative for distant education of students). Medychna osvita, 1, 135-139. DOI: 10.11603/me.2414-5998.2019.1.9445

Kocdar, S., Karadeniz, A., Peytcheva-Forsyth, R., \& Stoeva, V. (2018). Cheating and plagiarism in e-assessment: Students' perspectives. Open Praxis, 10, 221-235.

Kornytska, Yu. (2021) Flipped ESP class: A solution for developing reading skills. Norwegian Journal of Development of the International Science, 54 (4), 16-22. DOI: 10.24412/34539875-2021-54-4-16-22

Lailatur Rofiah, N. \& Waluyo, B. (2020). Using Socrative for Vocabulary Tests: Thai EFL Learner Acceptance and Perceived Risk of Cheating. Journal of Asia, 17, 966-982. DOI: 10.18823/asiatefl.2020.17.3.14.966.

Koyantayeva, M. (2019). Formative assessment in higher education: use of online apps and learning platform. Vestnik KazNU. Seriya pedagogicheskaya, 61, 74-84. DOI: 10.26577/JES.2019.v61.i4.09.

Lim, W. N. (2017). Improving student engagement in higher education through mobile-based interactive teaching model using Socrative. IEEE Global Engineering Education Conference (EDUCON), 404-412. DOI: 10.1109/EDUCON.2017.7942879.

Marienko, M., Nosenko, Y., Sukhikh, A., Tataurov, V., \& Shyshkina, M. (2020). Personalization of learning through adaptive technologies in the context of sustainable development of teachers' education. E3S Web of Conferences, 166. DOI: 10015. 10.1051/e3sconf/202016610015.

McLaughlin, T., \& Yan, Z. (2017). Diverse delivery methods and strong psychological benefits: A review of online formative assessment. Journal of Computer Assisted Learning, 33, 562-574. DOI: $10.1111 /$ jcal. 12200

Meet Socrative (n.d.). Retrieved from www.Socrative.com

Moin, H., Majeed, S., Irshad, K., Shafi, R., Yousaf. A., \& Ashraf, I. (2020). Introducing Socrative as a formative assessment tool in the undergraduate medical curriculum. PJP, 16(2), 21-25.

Nawalaniec, N. (2015). Socrative (Snowy release). Journal of the Medical Library Association, 103(4), 236-239. DOI: 10.3163/1536-5050.103.4.020

Ohashi, L. (2015). Enhancing EFL writing courses with the online student response system Socrative. Kokusaikeiei Bunkakenkyu, 19(1), 135-145.

Potapov, V. O., Khaskhachykh, D. A., Demchenko, T. V., Harahulia, I. S., \& Chuiko, V. I. (2017). Uprovadzhennia internet-servisu Socrative u navchalnu robotu studentiv medychnykh vuziv. (Introducing internet service Socrative into higher medical education). Medychna osvita, 2. doi: 10.11603/me.2414-5998.2017.2.7709

Prashanti, E., Ramnarayan, K. (2019). Ten maxims of formative assessment. Advances in Physiology Education, 43 (2), 99-102. DOI: 10.1152/advan.00173.2018

Pryke, S. (2020). The use of Socrative in university social science teaching. Learning and Teaching, 13(1), 67-86. doi:10.3167/latiss.2020.130105.

Rae, M. G., O'Malley D. (2017). Using an online student response system, Socrative, to facilitate active learning of Physiology by first-year graduate entry to medicine students: A feasibility study. Mede Publish 6, 1, 1-17. DOI: 10.15694/mep.2017.000004.

Royer, R. (2016). A comparison of eight digital tools for formative assessment. E-Learn: World Conference on E-Learning. Washington, USA: Association for the Advancement of Computing in Education, 113-118. 
Tretinjak, M. F., Bednjanec A. and Tretinjak M. (2015). Interactive teaching with Socrative. 38th International Convention on Information and Communication Technology, Electronics and Microelectronics (MIPRO), 848-85. DOI: 10.1109/MIPRO.2015.716039.

Valiente, B., Cazevieille, F. O., Jover, J. M. N. (2016). Online quizzes to evaluate comprehension and integration skills. Journal of Technology and Science Education, 2, 75-90. doi: dx.doi.org/10.3926/jotse.189

Vettori, M., Bos, A.S., Donato, L.G. and Zaro, M.A. (2020). The use of the Socrative application to enhance student attention: electroencephalography data of attention levels. International Journal for Innovation Education and Research, 8, (11) (Nov. 2020), 8697. DOI:10.31686/ijier.vol8.iss11.2722.

Weurlander, M., Söderberg, M., Scheja, M., Hult, H., \& Wernerson, A. (2012). Exploring formative assessment as a tool for learning: students' experiences of different methods of formative assessment. Assessment and Evaluation in Higher Education, 37 (6), 747-760. DOI: $10.1080 / 02602938.2011 .572153$.

Wood, J. (2020). Socrative in the Language Classroom: Tackling Classroom Anxiety and Encouraging Participation. 6th International Conference on Higher Education Advances (HEAd'20), Universitat Politecnica de Valencia, Valencia. DOI: 10.4995/HEAd20.2020.11231.

World health Organization. (2021). Advice for the public: Coronavirus disease (COVID-19). Retrived from www.who.int/emergencies/diseases/novel-coronavirus-2019/advice-forpublic.

Zavizion VF, Bondarenko IM, Avierin DI, Hojouj MI, Davlietova NO, Cherednychenlo NO, Prokhach AV, Mashtaler VE, Dmytrenko KO, Lohvynenko VV, Kyslytsyna VS, Sukhoversha OA, Khvorostenko YM, Elhajj MH, Suzdalev PL, Myroniuk TF, Kichtenko IN, Hrabovskyi YV, Smolina KV, Baranov IV. Distance learning: opportunities and challenges in quarantine. Med. Perspekt, 25(2), 4-12. 